\title{
PELAYANAN KESEHATAN VIRTUAL PADA PASIEN GAGAL JANTUNG SELAMA PANDEMI COVID-19; SEBUAH TINJAUAN LITERATUR
}

\author{
Bambang Aditya Nugraha ${ }^{1}$, Sulastini ${ }^{2}$, Sandra Pebrianti ${ }^{3}$, Gusgus Ghraha Ramdhanie ${ }^{4}$ \\ ${ }^{1,3,4}$ Fakultas Keperawatan Universitas Padjadjaran \\ ${ }^{2}$ STIKES Karsa Husada Garut \\ bambang14005@unpad.ac.id
}

\begin{abstract}
Heart failure is a chronic disease whose therapeutic regimen must be carried out continuously in order to maintain circulation and minimize deterioration. The covid-19 pandemic has prevented heart failure patients from getting health services directly. Remote or virtual health services can be carried out for patients with heart failure in order to prevent the spread and transmission of Covid 19 and maintain quality of life. The purpose of this literature is to explain that health care for patients with heart failure can be done virtually.

The research method used is narrative review using Google Scholar and pubmed as the database of articles. Article inclusion criteria are published during the COVID-19 pandemic, in Indonesian and in English, and a complete manuscript is available. The keywords used virtual care and heart failure and covid-19.

The search results showed 1392 articles, but only 5 articles that matched the predetermined criteria and it was found that virtual health services for heart failure patients were recommended to be carried out in order to meet patient needs and prevent the spread and transmission of covid 19. The search results were expected to become information related to alternative health services for patients with heart failure during the pandemic and improve quality of life.
\end{abstract}

Key Words - care, covid-19, heart failure, virtual health service

\section{PENDAHULUAN}

Covid-19 merupakan penyakit yang disebabkan oleh corona virus, menyebar lewat udara serta menyerang sistem pernapasan (World Health Organization, 2020). Covid-19 telah menjadi pandemi secara global dan mengharuskan setiap orang untuk menjaga jarak untuk mencegah penyebaran dan penularan covid 19 (Abraham, W. T., Fiuzat, M., Psotka, M. A., \& O'Connor, C. M., 2020), Mengurangi aktivitas di luar rumah dan menghindari kontak fisik dengan orang lain menjadi salah satu masalah yang menghambat penderita gagal jantung mendapatkan pelayanan kesehatan secara langsung. Pasien gagal jantung harus menghindari terinfeksi Virus Corona. Beberapa hasil penelitian menunjukkan bahwa gangguan pada sistem kardiovaskuler menjadi komorbid pada pasien yang terinfeksi dengan virus Corona yang berimplikasi pada perburukan kondisi dan penurunan angka harapan hidup pada pasien tersebut (Dong, N., Cai, J., Zhou, Y., Liu, J., \& Li, F., 2020). Kondisi pasien semakin memburuk jika pasien memiliki komorbid lain seperti diabetes (Apicella, M., Campopiano, M. C., Mantuano, M., Mazoni, L., Coppelli, A., \& Del Prato, S., 2020), tuberkulosis (Kumar, R., Bhattacharya, B., Meena, V., Soneja, M., \& Wig, N., 2020), dan usia lanjut. 
Gagal jantung berarti kegagalan jantung mempertahankan sirkulasi baik itu sistemik, pulmonal dan atau keduanya yang berdampak pada kegagalan multi organ (Anderson, P. S., \& Wilson, M., 2013) .Gagal jantung merupakan penyakit kronis yang mengharuskan penderitanya mendapatkan regimen terapi pengobatan secara terus-menerus dengan tujuan mempertahankan sirkulasi, mencegah perburukan (Black, J.M., \& Hawks, J.K., 2014) dan mempertahankan kualitas hidup. Berkaitan dengan masalah tersebut maka perlu disusun strategi dan alternatif supaya pasien gagal jantung tetap mendapatkan akses kepada layanan kesehatan sesuai dengan kebutuhan.

Salah satu opsi bagi petugas kesehatan untuk memberikan pelayanan kepada pasien selama pandemi adalah dengan memberikan pelayanan virtual (Jnr, B. A., 2020) atau pelayanan jarak jauh melalui transmisi video gambar maupun suara bantuan gawai. Pelayanan kesehatan virtual dipercaya mampu mencegah penyebaran dan penularan convid-19 karena tidak memerlukan kontak langsung antara petugas kesehatan dan pasien gagal jantung. Intervensi tersebut dianggap potensial untuk mengatasi permasalahan pelayanan kesehatan akibat pandemi covid 19. Hasil penelitian osik, J., Fudim, M., Cameron, B., Gellad, Z. F., Cho, A., Phinney, D., ... \& Katz, J. N. (2020) menunjukkan bahwa pelayanan kesehatan secara virtual dapat dilakukan pada penyakit tertentu tanpa meningkatkan resiko penyebaran maupun penularan covid 19. Misalnya hasil penelitian sia menunjukkan bahwa pelayanan kesehatan virtual berbentuk telehealth atau telenursing dapat memnuhi kebutuhan pelayanan kesehatan pada pasien dengan penyakit kronis. Dengan demikian pelayanan kesehatan virtual juga dapat dilakukan pada kasus gagal jantung
Pelayanan kesehatan virtual meliputi pengkajian fisik berdasarkan observasi dan wawancara, pelaporan simptom, manajemen nutrisi, manajemen aktivitas, peresepan obat sampai dengan peresepan latihan untuk rehabilitasi. Sama halnya dengan penyakit kronis lainnya, pada pasien gagal jantung, pelayanan virtual mayoritas berhubungan dengan peresepan obat tanpa harus datang ke fasilitass kesehatan di masa pandemi covid-19.

Tujuan dilakukannya tinjauan literatur ini adalah untuk menjelaskan bahwa pelayanan kesehatan pasien dengan gagal jantung dapat dilakukan secara virtual dalam rangka mencegah penularan dan penyebaran covid-19.

\section{METODE}

Desain penelitian yang digunakan pada penelitian ini adalah tinjauan literatur yang berfokus pada pelayanan kesehatan virtual pada pasien gagal jantung selama pandemi covid-19. Pertanyaan penelitian berdasarkan populasi intervensi dan konteks. Populasi pada penelitian ini adalah pasien gagal jantung, intervensinya adalah pelayanan kesehatan virtual dan konteksnya adalah Pandemi covid-19. Kriteria inklusi artikel pada penelitian ini adalah artikel yang berbahasa Indonesia dan Inggris berfokus pada pelayanan kesehatan virtual pasien gagal jantung tersedia abstrak dan full teks, serta diterbitkan selama pandemi covid 19. Sedangkan kriteria eksklusi artikel pada penelitian ini adalah artikel yang belum dipublikasikan atau berupa studi pendahuluan, pilot project, meta-analysis dan Protocol study.

Strategi pencarian artikel dalam penelitian ini dilakukan di database yaitu Google Scholar dan Pubmed. Kata kunci yang digunakan adalah pelayanan kesehatan virtual, gagal jantung dan covid-19. Artikel yang muncul saat pencarian dan sesuai dengan kriteria 
yang telah ditetapkan, selanjutnya dianalisis berdasarkan tema dan kontennya. Artikel dinilai berdasarkan karakteristik populasi yang diteliti, intervensi yang digunakan, dan harus memasukkan covid 19 sebagai salah satu konteks pada penelitian di dalam artikel tersebut. Pada saat penilaian, peneliti memperhatikan pola, perbedaan dan kesamaan masing-masing artikel dengan tujuan penelitian yang telah ditetapkan.

\section{Pencarian artikel dengan menggunakan kriteria inklusi dan kata kunci yang spesifik \\ Analisis artikel berdasarkan tema dan kontennya \\ Penilaian artikel berdasarkan karakteristik populasi yang diteliti, intervensi yang digunakan \\ $\downarrow$ \\ Ektraksi artikel kedalam bentuk tabel \\ 5 (lima) artikel yang sesuai dengan tujuan penelitian}

\section{HASIL}

Hasil penelusuran menunjukkan sebanyak 2,640 artikel yang muncul pada saat pencarian namun setelah dilakukan analisis, sekian artikel yang sesuai dengan kriteria yang telah ditetapkan sebelumnya. Berikut ini disajikan artikel hasil penelusuran yang berfokus pada pelayanan kesehatan virtual pada pasien dengan gagal jantung. Berdasarkan tabel tersebut, dapat diketahui bahwa Pelayanan kesehatan virtual pada pasien gagal jantung tidak terbatas pada aspek pengobatan saja namun dapat dilakukan pada pasien gagal jantung yang sedang menjalani rehabilitasi.

\section{Table. 2 Virtual Health Service On Heart Faillure Patient}

\begin{tabular}{|c|c|c|c|}
\hline Author & Tahun & Judul & Hasil \\
\hline $\begin{array}{l}\text { Umapathi, P., Cuomo, } \\
\text { K., Riley, S., Hubbard, } \\
\text { A., Menzel, K., Sauer, } \\
\text { E., \& Gilotra, N. A. }\end{array}$ & 2020 & $\begin{array}{l}\text { Transforming ambulatory } \\
\text { heart failure care in the } \\
\text { coronavirus disease- } 19 \text { era: } \\
\text { initial experience from a heart } \\
\text { failure disease management c }\end{array}$ & $\begin{array}{l}\text { Anjuran untuk Optimalisasi } \\
\text { telemedicine dan kunjungan virtual } \\
\text { dalam pengelolaan paien gagal } \\
\text { jatung selama pandemi covid-19 }\end{array}$ \\
\hline Gorodeski, Et.al & 2020 & $\begin{array}{l}\text { Virtual visits for care of } \\
\text { patients with heart failure in } \\
\text { the era of COVID-19: a } \\
\text { statement from the Heart } \\
\text { Failure Society of America }\end{array}$ & $\begin{array}{l}\text { Anjuran untuk penyelenggaraan } \\
\text { Kunjungan virtual dalam merawat } \\
\text { pasien gagal jantung merupakan } \\
\text { alternatif dan inovai yang } \\
\text { dibutuhkan selama pandemi }\end{array}$ \\
\hline $\begin{array}{l}\text { Thomas, E., Gallagher, } \\
\text { R., \& Grace, S. L. }\end{array}$ & 2020 & $\begin{array}{l}\text { Future-proofing } r \text { cardiac } \\
\text { rehabilitation: } \text { Transitioning } \\
\text { services to telehealth during } \\
\text { COVID-19 }\end{array}$ & $\begin{array}{l}\text { Anjuran untuk menyelenggarakan } \\
\text { telehealth pada pasien dengan } \\
\text { rehabilitasi jantung }\end{array}$ \\
\hline $\begin{array}{l}\text { Neubeck, L., Hansen, T., } \\
\text { Jaarsma, T., Klompstra, } \\
\text { L., \& Gallagher, R. }\end{array}$ & 2020 & $\begin{array}{l}\text { Delivering healthcare remotely } \\
\text { to cardiovascular patients } \\
\text { during COVID-19: A rapid } \\
\text { review of the evidence }\end{array}$ & $\begin{array}{l}\text { Untuk mendukung orang yang } \\
\text { hidup dengan penyakit } \\
\text { kardiovaskular selama isolasi } \\
\text { COVID-19 dan untuk mengurangi } \\
\text { efek karantina dan efek buruk pada } \\
\text { kesehatan mental dan fisik, petugas } \\
\text { kesehatan harus menawarkan } \\
\text { perawatan kesehatan jarak jauh. }\end{array}$ \\
\hline
\end{tabular}




\begin{tabular}{lclllr}
\hline \multicolumn{1}{c}{ Author } & Tahun & \multicolumn{2}{c}{ Judul } & Hasil \\
\hline Salzano, A., D'Assante, & 2020 & Heart failure management & layanan & telemedicine \\
R., Stagnaro, F. M., & & during the COVID-19 & memungkinkan pasien gagal \\
Valente, V., Crisci, G., & & outbreak in Italy: a jantung untuk ditindaklanjuti juga \\
Giardino, F., ... \& & & telemedicine experience from & \\
Cittadini, A. & & a heart failure university & \\
& tertiary referral centre & \\
\hline
\end{tabular}

\section{PEMBAHASAN}

Regimen pengobatan pada pasien gagal jantung harus terus dilaksanakan supaya tidak terjadi perburukan. Dengan adanya pandemi covid 19 maka regimen pengobatan pasien gagal jantung tidak bisa ditemukan secara langsung berkaitan dengan pencegahan penularan dan penyebaran covid-19 salah satunya dengan physical distancing. Perawatan secara virtual merupakan salah satu alternatif yang bisa dilakukan untuk mencegah penyebaran dan penularan covid 19. Metode tersebut sudah dilakukan sebelum adanya pandemi terutama berkaitan dengan cost-effective sebuah tindakan, ditujukan kepada pasien yang memiliki tempat tinggal jauh dari fasilitas kesehatan. Penelitian Behzad, Y., Hagani, H., \& Bastani, F. (2016) menunjukkan bahwa telenursing dapat dilakukan untuk mempermudah pasien yang tinggal jauh dari fasilitas kesehatan intervensi tersebut terbukti efektif dalam memelihara kondisi fisik pasien.

Penelitian Shohani, M., Mozafari, M., Khorshidi, A., \& Lotfi, S. (2018), unjukkan bahwa intervensi virtual memiliki efek yang sama dengan tatap muka langsung untuk kasus-kasus tertentu. Intervensi yang dilakukan berbasis panggilan telepon dan belum menggunakan panggilan video ataupun software spesifik dengan platform Android Windows atau Mac OS. Hasil penelitian de Thurah, A., Bremander, A., \& Primdahl, J. (2020) menunjukkan bahwa tatap muka secara virtual akan lebih baik dibandingkan dengan panggilan saja. Kondisi tersebut mengarahkan pada tren perawatan virtual berupa panggilan telepon dan video serta interface yang lebih interaktif serta mudah digunakan oleh pasien saat perawatan virtual. Perawat diharapkan mampu mengembangkan perawatan virtual pada semua kasus terutama gagal jantung untuk mempermudah pada saat memberikan pelayanan dan dapat menjangkau semua pasien yang berada jauh dari fasilitas kesehatan.

Pelayanan kesehatan virtual meliputi pelaporan symptom dan manajemen symptom yang didapatkan berdasarkan observasi dan wawancara secara online. Petugas kesehatan dapat memberikan arahan secara langsung ataupun dikirimkan berbentuk pesan suara atau teks kepada pasien dengan melampirkan data-data yang diperlukan sesuai dengan kondisi dan kebutuhan pasien. Di beberapa institusi resep dikirimkan kepada pasien yang selanjutnya dapat diambil di apotek terdekat yang berada di lingkungan sekitar pasien. Permasalahan yang sering ditemui pada saat pelayanan kesehatan virtual adalah ketidakmampuan pasien dalam menggunakan peralatan penunjang terutama pada pasien lansia. Selain itu, kendala jaringan menjadi salah satu hambatan yang ditemui pada pasien yang tinggal berada jauh dari transceiver terdekat solusinya adalah menyediakan koneksi langsung lewat satelit.

Pelayanan virtual tidak hanya dilakukan pada proses pengobatan tetapi juga bisa dilakukan pada saat rehabilitasi pada pasien kronis maupun fase akut contoh intervensi virtual pada pasien 
kronis adalah rehabilitasi pada pasien dengan rheumatologi (de Thurah, A., Bremander, A., \& Primdahl, J., 2020) hasil penelitian menunjukkan bahwa pelayanan kesehatan virtual dapat meningkatkan level kemandirian pasien Hicks, S. A., \& Cimarolli, V. R. (2018). Demikian pelayanan kesehatan virtual dapat dilakukan pada setiap fase dari preventif promotif kuratif sampai dengan rehabilitatif. Meski demikian, Sebelum diaplikasikan langsung kepada pasien dengan gagal jantung, intervensi pelayanan virtual diharapkan diuji terlebih dahulu untuk melihat efektivitas manfaat dan permasalahan yang mungkin muncul pada saat dilakukan intervensi tersebut baik itu pada pasien gagal jantung ataupun penyakit lainnya yang membutuhkan pelayanan kesehatan secara berkelanjutan Dalam rangka mempertahankan kualitas hidup.

Aplikasi pelayanan kesehatan virtual di negara Indonesia belum sepenuhnya bisa dilakukan berkaitan dengan infrastruktur komunikasi yang belum merata di seluruh negeri. Berapa wilayah belum dilengkapi dengan tingkat seluler atau jaringan internet. Selain itu, itu ke layanan kesehatan virtual yang berbasis Android atau telepon pintar akan membebani pasien mengingat tidak semua anggota masyarakat memiliki peralatan tersebut. Alternatif Solusi yang ditawarkan oleh peneliti adalah bekerja sama dengan kantor pemerintah, kepolisian dan militer yang sudah dilengkapi dengan jaringan komunikasi secara baik dengan tetap memperhatikan protokol kesehatan pencegahan dan penyebaran covid-19.

\section{PENUTUP}

Kesimpulan

Pelayanan kesehatan pada pasien gagal jantung harus terus dilakukan untuk mencegah perburukan dan meningkatkan kualitas hidup selama pandemi covid 19. Pelayanan kesehatan virtual menjadi salah satu alternatif bagi petugas kesehatan selama pandemi pada pasien gagal jantung karena mampu mencegah penyebaran dan penularan covid 19.

Saran

Hasil penelitian diharapkan dapat dijadikan informasi bagi petugas kesehatan untuk menyusun strategi pelayanan kesehatan pada pasien gagal jantung selama pandemi dengan tetap memperhatikan protokol kesehatan seperti menjaga jarak, mengurangi kontak fisik dan sebagainya

\section{REFERENSI}

Abraham, W. T., Fiuzat, M., Psotka, M. A., \& O'Connor, C. M. (2020). Heart Failure Collaboratory Statement on Remote Monitoring and Social Distancing in the Landscape of COVID-19. Jacc. Heart Failure, 8(8), 692.

Anderson, P. S., \& Wilson, M. (2013). Patofisiologi konsep klinis proses penyakit. Jakarta: EGC.

Apicella, M., Campopiano, M. C., Mantuano, M., Mazoni, L., Coppelli, A., \& Del Prato, S. (2020). COVID-19 in people with diabetes: understanding the reasons for worse outcomes. The lancet Diabetes \& endocrinology.

Behzad, Y., Hagani, H., \& Bastani, F. A. R. I. D. E. H. (2016). Effect of empowerment program with the telephone follow-up (telenursing) on self-efficacy in selfcare behaviors in hypertensive older adults. The Journal of Urmia Nursing and Midwifery Faculty, 13(11), 1004-1015.

Black, J.M., \& Hawks, J.K. (2014). Medical Surgical Nursing: Clinical Management for Positive Outcomes, Volume II, 7th Edition. Elsevier's Health Science Right Departement: Philadelphia 
de Thurah, A., Bremander, A., \& Primdahl, J. (2020). High-quality RMD rehabilitation and telehealth: Evidence and clinical practice. Best Practice \& Research Clinical Rheumatology, 101513.

Dong, N., Cai, J., Zhou, Y., Liu, J., \& Li, F. (2020). End-stage heart failure with COVID-19: strong evidence of myocardial injury by 2019nCoV. JACC: Heart Failur

Gorodeski, E. Z., Goyal, P., Cox, Z. L., Thibodeau, J. T., Reay, R. E., Rasmusson, K., ... \& Starling, R. C. (2020). Virtual visits for care of patients with heart failure in the era of COVID-19: a statement from the Heart Failure Society of America. Journal of Cardiac Failure.

Hicks, S. A., \& Cimarolli, V. R. (2018). The effects of telehealth use for post-acute rehabilitation patient outcomes. Journal of telemedicine and telecare, 24(3), 179-184.

Jnr, B. A. (2020). Use of telemedicine and virtual care for remote treatment in response to COVID19 pandemic. Journal of Medical Systems, 44(7), 1-9.

Kumar, R., Bhattacharya, B., Meena, V., Soneja, M., \& Wig, N. (2020). COVID-19 and TB co-infection'Finishing touch"in perfect recipe to'severity' or 'death'. Journal of Infection, 81(3), e39-e40.

Neubeck, L., Hansen, T., Jaarsma, T., Klompstra, L., \& Gallagher, R. (2020). Delivering healthcare remotely to cardiovascular patients during COVID-19: A rapid review of the evidence. European Journal of Cardiovascular Nursing, 1474515120924530.

Portnoy, J., Waller, M., \& Elliott, T. (2020). Telemedicine in the Era of COVID-19. The Journal of Allergy and Clinical Immunology: In Practice, 8(5), 1489-1491.

Salzano, A., D'Assante, R., Stagnaro, F. M., Valente, V., Crisci, G., Giardino, F., ... \& Cittadini, A. (2020). Heart failure management during the COVID-19 outbreak in Italy: a telemedicine experience from a heart failure university tertiary referral centre. European Journal of Heart Failure, 22(6), 10481050.

Sayer, G., Horn, E. M., Farr, M. A., Axsom, K., Kleet, A., Gjerde, C., ... \& Halik, C. (2020). Transition of a Large Tertiary Heart Failure Program in Response to the COVID-19 Pandemic: Changes That Will Endure. Circulation: Heart Failure, CIRCHEARTFAILURE-120.

Thomas, E., Gallagher, R., \& Grace, S. L. (2020). Future-proofing cardiac rehabilitation: Transitioning services to telehealth during COVID-19. European Journal of Preventive Cardiology, 2047487320922926.

Thomas, E., Gallagher, R., \& Grace, S. L. (2020). Future-proofing cardiac rehabilitation: Transitioning services to telehealth during COVID-19. European Journal of Preventive Cardiology, 2047487320922926.

Umapathi, P., Cuomo, K., Riley, S. Hubbard, A., Menzel, K., Sauer, E., \& Gilotra, N. A. (2020). Transforming ambulatory heart failure care in the coronavirus disease-19 era: initial experience from a heart failure disease management clinic. Journal of Cardiac Failure.

World Health Organization. (2020). WHO COVID-19 case definition 
(No.

WHO/2019-

nCoV/Surveillance_Case_Definit ion/2020.1). World Health Organization.

Wosik, J., Fudim, M., Cameron, B., Gellad, Z. F., Cho, A., Phinney, D., .. \& Katz, J. N. (2020). Telehealth Transformation: COVID-19 and the rise of Virtual Care. Journal of the American Medical Informatics Association, 27(6), 957-962.Shohani, M., Mozafari, M., Khorshidi, A., \& Lotfi, S. (2018). Comparing the effects of face-to-face and telenursing education on the quality of family caregivers caring in patients with cancer. Journal of family medicine and primary care, 7(6), 1209. 